\title{
Study of maternal and fetal outcomes in premature rupture of membrane in central rural India
}

\author{
Arpita A. Jaiswal*, C. Hariharan, Deepika K. C. Dewani
}

Department of Obstetrics and Gynecology, Jawaharlal Nehru Medical College, Sawangi, Wardha, Maharashtra, India

Received: 19 January 2017

Accepted: 28 February 2017

\section{*Correspondence:}

Dr. Arpita A. Jaiswal,

E-mail: drarpitajaiswal@gmail.com

Copyright: (c) the author(s), publisher and licensee Medip Academy. This is an open-access article distributed under the terms of the Creative Commons Attribution Non-Commercial License, which permits unrestricted non-commercial use, distribution, and reproduction in any medium, provided the original work is properly cited.

\section{ABSTRACT}

Background: Premature rupture of membrane is linked to significant maternal prenatal mortalities and morbidity. The maternal and fetal outcomes in PROM is very important to decrease maternal and child mortality and for better management and prevention of complications. Thus, this study aimed to detect the maternal and fetal outcomes in patients with PLROM at tertiary care hospital in central rural India.

Methods: This prospective study was conducted in Department of obstetrics \& Gynecology, in a tertiary care institute located in central India, over a period of 18 months. 210 patients were diagnosed with PLROM and all of them were included in the study. The data of these women were collected using a checklist based on registration books.

Results: The rate of maternal morbidity was $26 \%$, commonest cause was clinical chorioamnionitis (11.9\%) followed by febrile illness seen in $10.5 \%$. No maternal mortality was seen in the study. Perinatal morbidity was seen in $30 \%$ of cases. Clinical early onset neonatal infection was the commonest cause for perinatal morbidity noticed in $23.8 \%$ of cases (50 out of 210). Perinatal mortality observed was $1.43 \%$ (3 out of 210 ). Birth asphyxia being the commonest cases of mortality.

Conclusions: Major maternal morbidity is chorioamnionitis (11.9\%). Major perinatal morbidity observed is early onset neonatal infection (24\%).

Keywords: Fetal outcomes, Maternal outcomes, Premature rupture of membrane

\section{INTRODUCTION}

Under normal circumstances, fetal membranes rupture during the active phase of labor. Once the membranes rupture the integrity of pregnancy is in jeopardy. Many complications like preterm labor, prolonged labor, dry labor chorio-amnionitis (CAM), congenital pneumonia, neonatal infection and even death of neonate might occur. It is common obstetric problem and one of the most common clinical event where a traditional pregnancy can turn into a high-risk situation for mother as well as fetus.

PLROM is a major cause for prematurity which leads to increase perinatal morbidity and mortality. Obi (2007) and Liu (2009) however have found in their separate studies in developing countries that incidence of PLROM is around 18-20\%. ${ }^{1,2}$ Preterm prelabor rupture of a membranes (PPLROM) occurs in $1-5 \%$ of all pregnancies. It is responsible for approximately $30-40 \%$ of all preterm birth.

Preterm delivery is the cause of $85 \%$ of neonatal morbidity and mortality. There are numerous possible fetal consequences of preterm delivery due to PLROM like respiratory distress syndrome, hypothermia, hypoglycaemia, jaundice, necrotizing enterocolitis, intraventricular haemorrhage, neurologic impairment, apnea, retrolental fibroplasias, bronchopulmonary dysplasia, patent ductus arteriosus, fetal limb contracture formation, pulmonary hypoplasia and neonatal sepsis 
depending upon gestational age and latency period. PLROM cause $20 \%$ of all neonatal deaths. Probable maternal complications are chorioamnionitis (3-30\%), endometritis and placental abruption. Recurrence of PLROM may occur in $20 \%$ cause.

Maternal complications include intra-amniotic infection, which occurs in 13\%-60\% of women with PLROM, placental abruption, and postpartum endometritis. ${ }^{3,4}$ Preterm birth, infection, hypertensive disease, and asphyxia are cited as the most common contributors to maternal and fetal mortality in developing countries (LMICs). ${ }^{5,6}$ Evidence suggests that the rupture of membrane is related to infection, ${ }^{7}$ membrane dysfunction on a molecular level, ${ }^{8}$ collagen destruction, and programmed cell death in fetal membranes. ${ }^{9,10}$ The complication risk of PLROM is increased if the mother has previous PROM, low body mass index, concomitant infection of the gestational tissues, and longer the time elapsed between the rupture and delivery. ${ }^{11}$

Diagnosis and proper management is very important to limit various fetal and maternal complications generally due to infection. The maternal and fetal outcome in PLROM is very important to decrease maternal and child mortality and for better management and prevention of complications. Thus, this study aims to determine maternal and fetal outcomes in PLROM among pregnant women who were admitted to the maternity or labor ward in our rural tertiary care hospital.

Aim and objective of the study was to determine major maternal and neonatal outcomes in patients of PLROM.

\section{METHODS}

This prospective study was conducted in Department of obstetrics \& Gynecology, in a tertiary care institute located in central India, over a period of 18 months, 210 pregnant women who reported to the labour room with premature rupture of membranes at or after 34 completed weeks to 41 weeks of gestation were analysed for maternal and perinatal outcome, after obtaining ethical clearance from the local ethical committee of the teaching hospital.

\section{RESULTS}

There was a total of 210 patients taken into the study. Following data was obtained.

The rate of maternal morbidity was $26 \%$ (54 out of 210), commonest was clinical chorio-amnionitis $1.9 \%$ (25 out of 210) followed by febrile morbidity seen in $10.5 \%$ (22 out of 210). Other maternal morbidities were in the form of wound infection- $1.4 \%$ (3 out of 210 ), LRTI- $0.5 \%$ of 210), MRP $0.5 \%$ ( 1 out of 210 ), puerperal sepsis $1.4 \%$ (3 out of 210). No maternal mortality was seen in the study.
Table 1: Maternal outcome.

\begin{tabular}{|llll|}
\hline \multirow{1}{*}{ Maternal } & Tutcome & Total & $\begin{array}{l}\text { Percentage } \\
(\%)\end{array}$ \\
\hline & Healthy & 156 & 74.3 \\
\cline { 2 - 4 } & $\begin{array}{l}\text { Febrile } \\
\text { morbidity }\end{array}$ & 22 & 10.5 \\
\cline { 2 - 4 } Maternal & Clinical CAM & 25 & 11.9 \\
\cline { 2 - 4 } Outcome & Wound Infection & 3 & 1.4 \\
\cline { 2 - 4 } & LRTI & 1 & 0.5 \\
\cline { 2 - 4 } & UTI & 1 & 0.5 \\
\cline { 2 - 4 } & PPH & 2 & 1.0 \\
\cline { 2 - 4 } & MRP & 1 & 0.5 \\
\cline { 2 - 4 } & Puerperal Sepsis & 3 & 1.4 \\
\hline Total & & $\mathbf{2 1 0}$ & $\mathbf{1 0 0 . 0}$ \\
\hline
\end{tabular}

Table 2: Perinatal outcome.

\begin{tabular}{|c|c|c|c|}
\hline \multicolumn{2}{|c|}{ Perinatal Outcome } & Total & $\begin{array}{l}\text { Percentage } \\
(\%)\end{array}$ \\
\hline \multirow{8}{*}{$\begin{array}{l}\text { Perinatal } \\
\text { outcome }\end{array}$} & Healthy & 146 & 69.52 \\
\hline & Birth Asphyxia & 13 & 6.19 \\
\hline & EONI & 51 & 24.29 \\
\hline & Late onset sepsis & 2 & 0.95 \\
\hline & Malformation & 1 & 0.48 \\
\hline & $\begin{array}{l}\text { Hyperbilirubi- } \\
\text { nemia }\end{array}$ & 6 & 2.86 \\
\hline & $\begin{array}{l}\text { Congenital } \\
\text { Pneumonia }\end{array}$ & \multicolumn{2}{|r|}{0.48} \\
\hline & $\begin{array}{l}\text { Perinatal } \\
\text { Mortality }\end{array}$ & 3 & 1.43 \\
\hline
\end{tabular}

Table 3: Neonatal Parameters

\begin{tabular}{|c|c|c|c|}
\hline \multicolumn{2}{|c|}{ Neonatal Parameters } & Total & Percentage $(\%)$ \\
\hline \multirow{4}{*}{$\begin{array}{l}\text { Birth } \\
\text { Weight } \\
\text { (gms) }\end{array}$} & $<1500$ & 2 & 0.95 \\
\hline & $1500-2000$ & 13 & 6.19 \\
\hline & $2000-2500$ & 58 & 27.62 \\
\hline & $>2500$ & 137 & 65.24 \\
\hline \multirow{2}{*}{$\begin{array}{l}\text { Apgar } \\
\text { Score }\end{array}$} & $<7$ & 13 & 6.19 \\
\hline & $>7$ & 197 & 93.81 \\
\hline \multirow{2}{*}{ Gender } & Male & 102 & 48.57 \\
\hline & Female & 108 & 51.43 \\
\hline \multirow{2}{*}{ CRP } & Positive & 43 & 20.5 \\
\hline & Negative & 167 & 79.5 \\
\hline \multirow{2}{*}{$\begin{array}{l}\text { Blood } \\
\text { Culture }\end{array}$} & Positive & 14 & 6.7 \\
\hline & Negative & 196 & 93.3 \\
\hline \multirow{2}{*}{$\begin{array}{l}\text { WBC } \\
\text { count }\end{array}$} & $<15000$ & 176 & 83.81 \\
\hline & $>15000$ & 34 & 16.19 \\
\hline
\end{tabular}

Perinatal morbidity was seen in $30 \%$ of cases. Clinical early onset neonatal infection was the commonest cause for perinatal morbidity noticed in $23.8 \%$ cases. Other perinatal morbidities were birth asphyxia $6.19 \%$ (13 out of 21 (hyperbilirubinemia $2.86 \%$ (6 out of 210 ), congenital pneumonia $0.5 \%$ (1 out 210), congenital malformations $0.48 \%$ ( 1 out of 210 ), late onset sepsis 
$0.95 \%$ out of 210$)$. Perinatal mortality observed was $1.43 \%$ (3 out of 210$)$.

Out of 210 newborns of mothers who were having prelabour premature rupture of membranes at 34-41 weeks' gestation $65 \%$ had birth weight more than 2500 grams, 35\% had low birth weight, $6.1 \%$ had one minute Apgar score less than 7, $102(48.5 \%)$ were male and 108 (51.4\%) were female, $43(20.5 \%)$ had C-Reactive protein positive, out of them $14(6.7 \%)$ were having blood culture growth positive and $34(16.1 \%)$ were having WBC count more than 15,000 .

\section{DISCUSSION}

PLROM is defined as spontaneous rupture of the membranes before the onset of labor; preterm prelabor Rupture of Membranes (PPLROM) includes those women presenting with PROM before 37 weeks' gestation. Mid-trimester PROM applies to those with premature membrane rupture at 14-26 weeks' gestation. ${ }^{12}$

ACOG (2007) have suggested that PPLROM complicates 2 to $4 \%$ of all singleton and 7 to $20 \%$ of twin pregnancies. $^{13}$ Getahun reported $5 \%$ incidence of PLROM. $^{14}$

\section{Maternal outcome and PLROM}

PLROM is associated with an increased risk of maternal morbidity. Maternal morbidity increased with increase in duration of PLROM. The rate of maternal morbidity was $26 \%$, Clinical chorio-amnionitis was found in $11.9 \%$ (25 out of 210) and next commonest was febrile morbidity seen in $10.5 \%$, other maternal morbidities were wound infection $(1.4 \%)$, LRTI $(0.5 \%)$, UTI $(0.5 \%)$, PPH (1\%), MRP $(0.5 \%)$, puerperal sepsis $(1.4 \%)$. No maternal mortality was seen in the study. In Kodkany study maternal morbidity was seen in $21 \%$ of cases of PLROM. ${ }^{15}$ Khashoggi (2004) Reported maternal morbidity including chorio-amnionitis (20.9\%), postpartum endometritis $(6.8 \%)$, abruption placenta $(4 \%)$ and septicemia $(0.5 \%) .{ }^{16}$ In our study the rate of clinical CAM was found to be low compared to others as we have a protocol of starting antibiotics in cases of PLROM.

\section{Perinatal outcome and PLROM}

The relationship of PLROM to the consequential fetal hazard is a matter of concern. In the present study, perinatal morbidity was seen in $30 \%$ of cases. Clinical early onset neonatal infection was the commonest cause for perinatal morbidity noticed in $23.8 \%$ (50 out of 210) of cases. Other perinatal morbidities were birth asphyxia $(6.19 \%)$, hyper-bilirubinemia $(2.86 \%)$, late onset sepsis $(0.95 \%)$, congenital malformations $(0.48 \%)$, congenital pneumonia $(0.48 \%)$, and perinatal mortality was $1.43 \%$ (3 out of 210). Two of the three neonatal deaths were due to birth asphyxia and one was due to multiple congenital malformations. Akter reported perinatal mortality rate has also been observed to be higher in association with PLROM. ${ }^{17}$ In study by Sanyal perinatal morbidity was $32 \%$ and mortality was 5\%. ${ }^{18}$ Pulmonary hypoplasia occurs in patients with PLROM that lasted longer than 2 weeks. Hence, in our study there was no neonate with pulmonary hyperplasia. Khashoggi 2004 reported the prenatal survival rate was $94.5 \%$ whereas neonatal outcomes included neonatal mortality $(5.5 \%)$, respiratory distress (15.9\%), sepsis (7.7\%), and necrotizing enterocolitis 1\%). ${ }^{19}$ Since we have included only the women with > 34 weeks' gestation and excluded the women with obstetric complications which could have given rise to compromised fetus, the perinatal mortality in our study was lesser than the other studies.

\section{CONCLUSION}

PLROM is an enigmatic condition associated with high risk of maternal and perinatal morbidity and mortality. The overall incidence of PLROM is $6.02 \%$ of all deliveries during the study period. Major maternal morbidity is chorioamnionitis (11.9\%). Major perinatal morbidity observed is early onset neonatal infection (24\%). Prediction of these morbidities is an important step in the management of infection-associated with PLROM.

\section{Funding: No funding sources}

Conflict of interest: None declared

Ethical approval: The study was approved by the Institutional Ethics Committee

\section{REFERENCES}

1. Obi S, Ozumba B. pre-term premature rupture of fetal membranes: the dilemma of management in a developing nation. Journal of obstetrics \& Gynecology. 2007;27(1):37-40.

2. Liu J, Feng $\mathrm{Z}-\mathrm{C}, \mathrm{Wu} \mathrm{J}$. The incidence rate of premature rupture of membranes and its influence on fetal -neonatal health: A Report from Mainland China. Journal of tropical paediatrics. 2009;51.

3. ACOG Committee on Practice Bulletins-Obstetrics. ACOG Practice Bulletin No. 80: premature rupture of membranes. Clinical management guidelines for obstetrician-gynecologists. Obstet Gynecol. 2007;109:1007-1019.

4. El-Messidi A, Cameron A. Diagnosis of premature rupture of membranes: inspiration from the past and insights for the future. J Obstet Gynaecol Can. 2010;32:561-569.

5. Vogel JP, Lee AC, Souza JP. Maternal morbidity and preterm birth in 22 low- and middle-income countries: a secondary analysis of the WHO Global Survey dataset. BMC Pregnancy Childbirth. 2014;14:56.

6. Beck S, Wojdyla D, Say L, Bertran AP, Merialdi M, Requejo $\mathrm{JH}$, et al. The worldwide incidence of preterm birth: a systematic review of maternal 
morbidity and mortality. Bull World Health Organ. 2010;88:31-38.

7. Naeye R, Peters E. Causes and consequences of premature rupture of fetal membranes. Lancet. 1980;1:192-194.

8. Moore RM, Mansour JM, Redline RW, Mercer BM, Moore JJ. The physiology of fetal membrane rupture: insight gained from the determination of physical properties. Placenta. 2006;27:1037-1051.

9. Mercer BM, Goldenberg RL, Meis PJ, Moawad AH, Shellhaas C, Das A, et al. The Preterm Prediction Study: prediction of preterm premature rupture of membranes through clinical findings and ancillary testing. The National Institute of Child Health and Human Development Maternal-Fetal Medicine Units Network. Am J Obstet Gynecol. 2000;183:738-745.

10. Mercer BM. Preterm premature rupture of the membranes. Obstet Gynecol. 2005;101:178-193.

11. Hackenhaar AA, Albernaz EP, da Fonseca TM. Preterm premature rupture of the fetal membranes: association with sociodemographic factors and maternal genitourinary infections. J Pediatr (Rio J) 2014;90:197-202.

12. Yang LC, Taylor DR, Kaufman HH, Hume R, Calhoun B. Maternal and Fetal outcome of spontaneous preterm premature rupture of membranes. JAOA: Journal of the American Osteopathic Association. 2004;104(12):537-42.

13. ACOG. Practice Bulletin No. 80: premature rupture of membranes. Clinical management guideline for obstetrician-gynaecologists. 2007;109(4):1009-19.
14. Getahun D, Ananth CV, Oyelese Y, Peltire MR, Smulian JC, Vintzileos AM. Acute and Chronic respiratory diseases in pregnancy: associations with spontaneous premature rupture of membranes. Journal of Maternal-fetal and Neonatal Medicine. 2007;20(9):669-75.

15. Kodkany B, Telang M. Premature rupture of membranes. A study of 100 cases. J Obstet Gynaecol India. 1991;41(4):492-6.

16. Veleminsky M, Pradna J, Veleminskt M, Tosner J. Relationship of amniotic-type placenta inflammation to $\mathrm{pPROM}, \mathrm{PROM}$ and risk of earlyb onsetbneonatal sepsis. Neuro endocrinology letters. 2008;29(4):44750.

17. Akter S, Akter R, Rashid M. Preterm prelaour Rupture of the Membrane \& Feto- maternal out come: an observational study. Journal of Bangladesh college of physicians and surgeons. 2010;28(1):1723.

18. Sanyal M, Mukherjee T. premature rupture of membranes; an assessment from a rural medical collage of west Bengal; J. J of Obstet Gynecol. 1990;40(5):623-8.

19. Khashoggi TY. Outcome of pregnancies with preterm premature rupture of membranes.Saudi medical journal. 2004;25(12):1957-61.

Cite this article as: Jaiswal AA, Hariharan C, Dewani DKC. Study of maternal and fetal outcomes in premature rupture of membrane in central rural india. Int J Reprod Contracept Obstet Gynecol 2017;6:1409-12. 